\title{
Strategies and Implementation Paths for Curriculum Setting of Digital Media Major in the Digital Age
}

\author{
https://doi.org/10.3991/ijet.v16i15.24887 \\ Zhiqi Zhou ${ }^{1}$, Bo Dong ${ }^{2(\varpi)}$ \\ ${ }^{1}$ Sanjiang University, Nanjing, China \\ ${ }^{2}$ Chuzhou Polytechnic College, Chuzhou, China \\ dongbo@chzc.edu.cn
}

\begin{abstract}
The professional courses of digital media major face several problems: too many influencing factors, unclear implementation strategy, and difficulty in evaluating the implementation effect. To solve these problems, this paper explores strategies and implementation paths for the professional courses of digital media major in the digital age. Firstly, the essential elements in curriculum setting were discussed, and the symptoms of the relevant problems were summarized; On this basis, the authors derived detailed strategies for the curriculum setting of digital media major. To ensure the effectiveness and reasonability of the professional courses of digital media major, an evaluation system and an evaluation model were constructed for judging the implementation effect of these courses. The research provides a strong support for the smooth implementation of the designed professional courses of digital media major, and a good reference for theorists and engineers in the relevant fields.
\end{abstract}

Keywords—digital media major, professional course, curriculum setting, digital age, fuzzy evaluation

\section{Introduction}

Whether the professional curriculum is reasonably set plays a vital role in the cultivation of talents, thus researching the setting of professional courses is of very important significance [1-2]. In the digital age, the society has an increasingly stronger requirement for digital media professionals. With the rapid development of modern science and technology, digital, informational, and intelligent techniques are gradually integrated into the training process of digital media talents. Therefore, how to merge these contents into the professional courses of digital media major and form a complete professional curriculum system of digital media major are quite meaningful for related research [3]. At present, the setting and teaching of professional courses have become hot topics in modern education research, and many scholars have conducted research and analysis from different perspectives and obtained corresponding research results [4-6].

Liao [7] attempted to reconstruct the professional curriculum system of digital media major based on the target ability development requirements of digital media ma- 
jor. Qin et al. [8] analyzed the problem of curriculum setting of digital media interaction major in the digital age, and discussed a new, reasonable, and standardized curriculum setting method that meets the teaching requirements. Duan et al. [9] analyzed the professional courses of digital media major from the aspects of theoretical basis, basic framework, basic content, and course practice, and constructed an improved professional course system with characteristics of digital media application technologies. Combining with the objective conditions of the talent requirements of enterprises and the characteristics and advantages of the curriculum setting of digital media major in different schools, Liu and $\mathrm{Mu}$ [10] established a set of complete course teaching system of digital media major, which can provide support for the development of the digital media major. Shu et al. [11] took the "Digital Media Design" course for printing engineering majors as an example to analyze the problems existing in curriculum setting from aspects of course teaching content and assessment plan, and they formed an assessment plan that can examine students' mastery of profession courses, self-learning ability cultivation, and professional knowledge application and operations, etc., which provided a very good reference for the curriculum setting of digital media major.

After summarizing and analyzing existing research results, we found that there're a few shortcomings with the current researches on the professional course setting in the digital age, especially those concerning the professional course setting of digital media major with higher requirements for digital media majors, such as the unclear teaching goals, the unsystematic professional course setting, and the imperfect effect evaluation methods and models for professional course setting, etc. For this purpose, based on related research results, this paper aims to analyze the essential issues of curriculum setting of digital media major in the digital age, and explore relevant strategies and corresponding implementation paths for the target problems. Then, by integrating entropy method [12-15], AHP [16-18], and gray system theory [19], this paper gives a multi-attribute fuzzy analysis model for assessing the implementation effect of the professional courses of digital media major, in the hopes of providing useful help for the effective curriculum setting of digital media major in the digital age. The research content of this paper consists of 7 parts: the first part gives an overview analysis of related research concerning the setting of professional courses in the digital age, especially the professional courses of the digital media major; the second part discusses the essence of the curriculum setting of digital media major in the digital age; the third part analyzes problems existing in the curriculum setting of digital media major in the digital age; the fourth part discusses strategies for the curriculum setting of digital media major in the digital age; the fifth part gives the implementation paths, the sixth part analyzes the implementation effect, and the seventh part is the conclusion. 


\section{Essential content in the curriculum setting of digital media major in the digital age}

\subsection{The curriculum setting of digital media major should conform to the professional curriculum system}

The digital media major requires not only a single professional course, but a complete professional curriculum system. As we all know, the setting of professional courses of the digital media major needs to comprehensively consider the professional knowledge and content of each learning stage, and these different course learning stages have very important impact on students' professional knowledge lecturing, professional knowledge reserve, and professional knowledge cognition. Therefore, in terms of the teaching and learning of professional courses, the curriculum setting of digital media major needs to consider not only the planning of professional knowledge, but also the systematicity, integrity, and logicality of courses, and it should be able to reflect the instruction ideas and planning schemes of the curriculum system of digital media major. The different professional courses of digital media major should be sorted out by their categories, and the curriculum system of digital media major is the sum of the teaching content and teaching progress of the professional courses of digital media major. The rank of the categories of the professional courses determines what professional knowledge structure would be acquired by the digital media major students through learning.

\subsection{The curriculum setting of digital media major should be closely linked to the training goals of professional talents}

The ultimate goal of curriculum setting of digital media major is to cultivate professionals with excellent comprehensive quality. Therefore, the curriculum setting of digital media major not only needs to conform to the teaching plans and teaching goals of the curriculum system of digital media major, but also needs to be closely linked to the training goals of digital media professionals. The curriculum system of digital media major is the ideology for instructing the training activities of digital media professionals, and it is the manifestation and basic support for the training goals of digital media professionals. For this reason, the curriculum setting of digital media major not only needs to formulate planning schemes for the implementation of the training goals of digital media professionals, but also needs to be able to reflect the course objectives, course ideas, course structure, course content, and course activities, so that they could better fit the training goals of digital media professionals. Under the guidance of training goals and value idea education concepts, the curriculum setting of digital media major should reasonably arrange and combine the various elements of digital media courses, so that they could unify and all point to the curriculum system of digital media major during the dynamic implementation process. The curriculum system of digital media major is the carrier to realize the training goals of 
digital media professionals, and the key to ensure and enhance the quality of digital media talents.

\subsection{The curriculum setting of digital media major should have the characteristics of the digital age}

The development of contemporary society has obvious digital, informational, and intelligent features, in such context, the demand for talents who can suit the development status of the society is quite urgent. As we all know that the 21 st century is an era of knowledge, its strong demand for senior professionals makes the cultivation of high-quality talents greatly valued by the society. To cultivate such high-quality talents with good social adaptability, it's necessary to pay attention to the planning and design of professional courses, besides systematicity, logicality, and professionalism, the curriculum setting of digital media major should also have social adaptability and contemporary features, so that the digital media majors could better fit the social requirements after learning these courses. Based on the teaching goals and development plans of the cultivation of digital media majors, digital, informational, and intelligent content should be added into the curriculum setting of digital media major so that the courses would have obvious digital age features, which is conductive to improving the educational environment of digital media major, improving the quality of cultivated digital media professionals, and improving the society's awareness of the educational concept of the cultivation of digital media professionals.

\subsection{The curriculum setting of digital media major should be conducive to the training of professional talents}

Just as the higher education, the planning of digital media major is undergoing a profound educational reform, in the context of the digital age in the 21 st century, the education of digital media major also puts forward corresponding demands for the quality development of digital media majors, and this requires the planning of the digital media major to incorporate contents such as the knowledge economy, information technology, intelligent technology, professional knowledge, and even the global integration development trends, moreover, it also needs to combine with the personality development of digital media majors to cultivate professionals with solid professional knowledge, strong ability to combine theory and practice, good creative thinking ability, sound personality, excellent scientific spirit and humanistic spirit, and outstanding comprehensive ability, in this way, the quality of digital media majors could be enhanced in a comprehensive way, and the cultivation of digital media professionals could form a benign development trend. Therefore, the outdated curriculum system, course structure, and course content of digital media major need to be fundamentally reformed, and a set of new curriculum system of digital media major should be established to better suit the cultivation of digital media majors. 


\section{Problems in the curriculum setting of digital media major in the digital age}

To figure out problems existing in the curriculum setting of digital media major, this study investigated the situations of curriculum planning and setting of digital media major in multiple schools; after summarizing and analyzing the survey results and related materials, we have concluded a few problems existing in the curriculum setting of digital media major:

(1) The contemporary features of the courses are not obvious: as mentioned above, in the digital age, the professional courses of the digital media major should have significant digital, informational, and intelligent contemporary characteristics, however, according to the survey results, due to multiple reasons such as the incomplete school system, limited software and hardware investment, incompetent administrators, insufficient government support, and poor school-enterprise collaboration, when schools are setting professional courses for the digital media major, they often come across problems such as the weak infrastructure, lacking of digital construction platforms, and flawed information systems, etc., obviously, these contradict the current digital, informational, and intelligent features of the times, as a result, the digital major courses lack the contemporary features of the digital age, and this is not good for cultivating high quality digital media professionals in the new era.

(2) The teaching content of courses is outdated: the digital media major of some schools still adopt the old teaching plans, and their curriculum systems are set based on the old teaching content, they haven't reformed the teaching content combining with current development status of the digital media technologies and the updated professional knowledge, which makes the current digital media major courses lack of innovativeness and contemporary features, as a result, the teaching content fails to touch students' actual development conditions, and the setting of the course content of digital media major is not in line with the teaching goals of modern education. In addition, since the new teaching content failed to be added to the curriculum in a timely and effective manner, it's difficult to systematically impart the knowledge system of the professional courses of digital media major.

(3) The systematicness of the courses needs to be further improved: the current curriculum system of the digital media major is not sound enough, which is mainly reflected in three aspects, first, the current curriculum system doesn't fully consider students' learning stages, that is, the teaching of general knowledge, basic knowledge, and professional knowledge is not closely related to the different learning stages of students; second, there isn't a set of complete course teaching system and it lacks the support of classic textbook series; third, the faculty of digital media major courses is deficient, there isn't a complete teacher team construction mechanism, which directly affects the sustainable development of the curriculum system.

(4) The social applicability of the curriculum system needs to be improved: as we all know, knowledge comes from society and is used in society, and only in this way can knowledge better promote the development of society. Similarly, if we want to cultivate high-quality digital media professionals, the social applicability of the digital media major courses must be improved. At present, the curriculum system of digital 
media major is not applicable enough to the social requirements, and this is reflected in three aspects, first, during the curriculum setting process, the theoretical knowledge is not highly integrated with the practical knowledge, although students have learnt the theories, they don't know how to use them; second, the curriculum setting hasn't take into account the actual social needs, especially the needs for professional knowledge and skills; third, the school-enterprise integration of digital media major courses is insufficient, although some schools have also built a few channels or platforms for school-enterprise integration, they merely stay in formality rather than explore the deeper-level internal relationships, especially in terms of industry-schoolresearch cooperation, the knowledge of digital media major courses hasn't been effectively converted.

Of course, besides above-mentioned problems in the curriculum setting of digital media major, different schools also have their respective issues during the curriculum setting process, and this requires researchers to give corresponding analysis based on specific conditions.

\section{Strategies for curriculum setting of digital media major in the digital age}

Since there are many problems existing in the curriculum setting of digital media major and they are limited by many constraints, in order to improve the quality of the curriculum system of digital media major and the quality of digital media professionals, corresponding strategies are required, and this paper proposes the following strategies for the curriculum setting of digital media major.

(1) The strategy of combining software and hardware

The strategy of combining software and hardware means to effectively joint the soft and hard forces of the setting and planning of digital media major courses. The soft force refers to the aspects of financial investment, teaching talent introduction, faculty team construction, and teaching material compilation. The hard force refers to the aspects of professional digital media platforms, information systems, hardware equipment and infrastructure, multi-media teaching centers, and comprehensive practice base, etc. The effective combination of these two forces can provide a solid basis for the improvement of the teaching ability of digital media major courses.

(2) The strategy of coordinating dynamic and static factors

The strategy of coordinating dynamic and static factors means to combine the typical factors and the required factors of the setting and planning of digital media major courses. The typical factors are the basic main line of the setting and planning of digital media major courses, and they are the guiding factors formulated for the training goals of digital media majors, factors of this type often remain unchanged within a certain period. The required factors mean that different social development stages and different times have different talent cultivation requirements, thus the required factors of the setting and planning of digital media major courses are a dynamic developing process. The strategy of coordinating dynamic and static factors aims at promoting the 
relevant factors to form an organic whole and provide powerful support for the curriculum setting of digital media major.

(3) The strategy of merging multi-levels and multi-dimensions

The strategy of merging multi-levels and multi-dimensions means to comprehensively consider the relationships among students, courses, and teachers during the curriculum setting and planning process. The merging of multi-levels means that the curriculum setting of digital media major should consider the different learning stages of different student individuals, apparently students of different learning stages have different levels of knowledge absorption ability, which requires the curriculum setting and teachers to teach in a targeted manner. The merging of multi-dimensions means to explore the correlations among different professional courses from different perspectives, as well as the development characteristics of different student groups, and the knowledge absorption of different student groups for different professional courses. Obviously, well applying the strategy of merging multi-levels and multidimensions can effectively enhance students' professional knowledge absorption ability.

(4) The strategy of aligning theory with practice

In terms of teaching content, the professional courses of digital media major have both strong theoretical and practical features. Therefore, during curriculum setting, the teaching plan of theoretical knowledge and professional knowledge and the ratio of teaching content should be well scheduled, neither should be ignored, or the logic and connection between the two will be cut; also, laying equal emphasis on every aspect is no good either, otherwise the key content cannot be highlighted. The authors hold that this requires us to well solve the hierarchical relationship between general knowledge, basic knowledge, professional knowledge, and practical knowledge in the digital media major courses, and efficiently carry out works in the course teaching of digital media major such as knowledge consolidation, knowledge transformation, knowledge application, and knowledge deepening, etc., then the comprehensive quality of digital media majors could be better enhanced.

(5) The strategy of promoting development through reform

The strategy of promoting development through reform means that the curriculum setting of digital media major should pay attention to the teaching reform and innovation of the professional courses, this is a systematic project that requires to comprehensively consider various aspects of the digital media major such as teaching content, course textbooks, teaching plans, teaching goals, industry-school-research framework and platform, teaching and administration system, and teaching rewards and punishment mechanisms, etc.

\section{$5 \quad$ Implementation paths for curriculum setting of digital media major in the digital age}

Under the guidance of above strategies, this paper proposes to take following measures to enhance the implementation effect of the curriculum setting of digital media major in the digital age: 


\subsection{Increase basic input to the construction of professional courses of digital media major}

In the digital age, the curriculum setting of digital media major must have digital, informational, and intelligent features, only in this way can it keep pace with the development of the times and meet the requirements of social development for digital media professionals. Thus, it's necessary to provide sufficient software and hardware conditions for the construction of professional courses of digital media major and enhance the sustainable development of the curriculum system. Moreover, the most fundamental guarantee for enhancing software and hardware conditions is to increase basic input to the construction of professional courses of digital media major, for this purpose, it could be achieved via various paths such as cooperate with government to construct the curriculum system together, introduce quality social resources, and form alliance with peer schools to help each other, etc.

\subsection{Build a good curriculum framework for digital media major}

Ultimately, the training of digital media professionals must be reflected in the imparting of professional knowledge, therefore, under the premise that there're good software and hardware conditions, we'll need to think about how to systematically impart the professional knowledge. Although the various intelligent software systems and hardware equipment could provide effective support for the professional courses of digital media major from aspects of teaching methods, means, and tools, the first thing to do is to ensure that the curriculum planning is heading towards the right direction and could provide good instructions, and this requires a good curriculum framework to provide the necessary guarantee. For this purpose, investigation and survey could be carried out to figure out the specific situations of the curriculum construction of digital media major, then schools could well plan the curriculum framework for digital media major and improve the guidance and normative quality of the knowledge imparting of digital media major courses.

\subsection{Build a faculty echelon of digital media major courses}

Faculty is the actual executors of the teaching activities of digital media major courses, and the professional competence of teachers in the faculty is an important guarantee for the effective implementation of course teaching. Under normal circumstances, teachers with incompetent professional quality can hardly impart the teaching content well; similarly, a faculty with a low overall quality can hardly build their teaching competitiveness, which is very detrimental to achieving the goal of training digital media professionals. Therefore, building a faculty echelon of digital media major is of very important significance, for this purpose, multiple methods could be adopted at the same time, such as introducing high-level teaching talents from other institutions or cultivating excellent young teaching talents in the school, in this way, we could build a faculty echelon of digital media major that can develop sustainably. 


\subsection{Improve the management system of curriculum planning of digital media major}

Management system is a basic guarantee for the curriculum planning of digital media major, a good teaching management system can effectively support the smooth implementation of various tasks in the curriculum planning of digital media major, and offer supportive conditions for completing teaching tasks successfully. On the contrary, an imperfect teaching management system tends to magnify problems existing in the curriculum planning of digital media major, thereby affecting the normal operation of teaching works and the realization of teaching tasks. Therefore, improving the management system of curriculum planning of digital media major is an important aspect to ensure the effectiveness of the curriculum planning of digital media major courses, and this requires the teaching administrators to fully consider various aspects and factors such as course situations, teaching conditions, teacher factors, student factors, and management factors, etc.

\subsection{Enhance industry-school-research integration of the curriculum planning of digital media major}

Judging from the current situations in the curriculum planning of digital media major in schools, generally, the teaching content involves the comprehensive imparting of theoretical and practical knowledge. Schools often plan the teaching content in hierarchies according to students' grades from high to low, and combine with the actual conditions of the teaching tasks to perform local minor adjustment to the teaching content. However, one thing should be noted is that such theory-practice integration might only be limited within the school campus, while it detaches from the real engineering practice. In addition, there's often the situation that although students have learnt the theoretical and practical knowledge, when it comes to the actual operations with specific tasks, they are not able to apply their knowledge to the actual works, let alone do innovative designs, and this indicates that the curriculum planning of digital media major has the problem of disconnection between learning and using, and this requires to enhance the integration of the digital media industry, the academic learning of students at schools, and the scientific research of digital media technologies, in this way, the social practicality of the professional courses of digital media major could be further improved, and the industry, the schools, and the research could promote each other, forming a industry-school-research mode that can develop healthily.

\subsection{Pay attention to the reform and innovation of digital media major courses}

Reform and innovation are the driving force for the continuous development of things, and they are also the basic guarantee conditions for things to keep sustainable competitiveness, and this is also true for the curriculum planning of digital media major. Because social development is a dynamic and progressive process, different eras and social stages generally have different demands for the professional courses of 
digital media major. If we keep using the old and outdated course content and curriculum system of digital media major, it'll make the curriculum setting of digital media major be inconsistent with the trend of social development, and the cultivated digital media majors will inevitably be out of touch with the development of the times. Therefore, the dynamic features of social development should be combined to reform and innovate the professional courses of digital media major in a targeted way, and such innovations should not only be limited to the aspects of teaching system, teaching content, teaching goals, teaching scheme, syllabus, teaching methods, and teaching tools, but also could be extended to aspects such as teaching ideas, teaching concepts, and teaching philosophies, etc., in this way, dynamic and developmental teaching ideas could be formed for the curriculum setting of digital media major.

\section{Implementation effect of digital media courses in the digital age}

\subsection{Implementation effect evaluation system}

To judge whether the curriculum setting of digital media major in the digital age is reasonable and effective or not, we need to borrow the help of the corresponding digital major course implementation effect evaluation system to make measurements. Based on investigation results, this paper constructed an implementation effect evaluation system of digital media courses from multiple aspects of course teaching process, course teaching effect, student ability training, student training effect, and teaching reform and development; the specific content is shown in Table 1.

\subsection{Evaluation index processing and weight analysis}

It can be seen from the content of the constructed implementation effect evaluation system that the valuation indexes might contain fuzzy information, and there're positive and negative indexes. To make the evaluation results more accurate and reliable, the various types of evaluation indexes must be normalized and assigned weight values before evaluation.

Suppose there're $M$ evaluation objects and $N$ evaluation indexes, the value of the $j$ th evaluation index of the $i$-th evaluation object $P_{i}$ is $V_{j}\left(P_{i}\right)=\left[v_{j}^{a}\left(P_{i}\right), v_{j}^{b}\left(P_{i}\right)\right]$, wherein $1 \leq i \leq M, 1 \leq j \leq N, v_{j}^{a}\left(P_{i}\right) \leq v_{j}^{b}\left(P_{i}\right)$. If the $j$-th evaluation index is a positive index, then its normalized value $V_{j}^{*}\left(P_{i}\right)$ is:

$V_{j}^{*}\left(P_{i}\right)=\left[v_{j}^{a *}\left(P_{i}\right), v_{j}^{b *}\left(P_{i}\right)\right]=\left(\frac{v_{j}^{a}\left(P_{i}\right)-\min _{1 \leq i \leq M} V_{j}\left(P_{i}\right)}{\max _{1 \leq i \leq M} V_{j}\left(P_{i}\right)-\min _{1 \leq i \leq M} V_{j}\left(P_{i}\right)}, \frac{v_{j}^{b}\left(P_{i}\right)-\min _{1 \leq i \leq M} V_{j}\left(P_{i}\right)}{\max _{1 \leq i \leq M} V_{j}\left(P_{i}\right)-\min _{1 \leq i \leq M} V_{j}\left(P_{i}\right)}\right)$

If the $j$-th evaluation index is a negative index, then its normalized value $V_{j}^{*}\left(P_{i}\right)$ is: 
Paper-Strategies and Implementation Paths for Curriculum Setting of Digital Media Major in the Digital...

Table 1. Implementation effect evaluation system of digital media courses

\begin{tabular}{|c|c|c|}
\hline Evaluation system & Evaluation criterion & Evaluation index \\
\hline \multirow{30}{*}{$\begin{array}{l}\text { Implementation effect } \\
\text { evaluation of digital } \\
\text { media courses }\end{array}$} & \multirow{6}{*}{$\begin{array}{l}\text { Course teaching } \\
\text { process }\end{array}$} & Teaching content is reasonable \\
\hline & & Teaching method is scientific \\
\hline & & Teaching environment is good \\
\hline & & Teaching scheme is systematic \\
\hline & & Teaching tool is advanced \\
\hline & & Teaching atmosphere is harmonious \\
\hline & \multirow{5}{*}{ Course teaching effect } & Satisfaction of supervisor \\
\hline & & Excellent rate of courses evaluated by students \\
\hline & & Non-qualified rate of courses evaluated by students \\
\hline & & Degree of completion of teaching tasks \\
\hline & & Degree of completion of teaching goals \\
\hline & \multirow{6}{*}{$\begin{array}{l}\text { Student ability train- } \\
\text { ing }\end{array}$} & Professional quality and level \\
\hline & & Innovation ability \\
\hline & & Thinking ability \\
\hline & & Communication and coordination ability \\
\hline & & Problem-solving ability \\
\hline & & Ability to integrate theory and practice \\
\hline & \multirow{5}{*}{ Student training effect } & Social satisfaction \\
\hline & & Student excellent rate \\
\hline & & Student failure rate \\
\hline & & Award-winning rate in professional contests \\
\hline & & Participation rate in professional contests \\
\hline & \multirow{8}{*}{$\begin{array}{l}\text { Teaching reform and } \\
\text { development }\end{array}$} & Teaching concept development \\
\hline & & Faculty construction \\
\hline & & Textbook compilation \\
\hline & & Number of teaching reform projects \\
\hline & & Number of teaching reform papers \\
\hline & & Number of award-winning teaching reform projects \\
\hline & & Number of industry-school-research platforms \\
\hline & & Number of teaching bases and systems \\
\hline
\end{tabular}

$V_{j}^{*}\left(P_{i}\right)=\left[v_{j}^{a *}\left(P_{i}\right), v_{j}^{b *}\left(P_{i}\right)\right]=\left(\frac{\max _{1 \leq i \leq M} V_{j}\left(P_{i}\right)-v_{j}^{b}\left(P_{i}\right)}{\max _{1 \leq i \leq M} V_{j}\left(P_{i}\right)-\min _{1 \leq i \leq M} V_{j}\left(P_{i}\right)}, \frac{\max _{1 \leq i \leq M} V_{j}\left(P_{i}\right)-v_{j}^{a}\left(P_{i}\right)}{\max _{1 \leq i \leq M} V_{j}\left(P_{i}\right)-\min _{1 \leq i \leq M} V_{j}\left(P_{i}\right)}\right)$

After all evaluation indexes were normalized, they had a unified measurement scale, and the differences in them had been eliminated, in this way, the evaluation results of the implementation effect of digital media courses would be more accurate.

There're both qualitative and quantitative evaluation indexes, since we couldn't give the accurate evaluation information of some evaluation indexes, the weight values of these indexes are somewhat subjective, therefore, the AHP method was adopted for processing. 
A few review experts were invited to evaluate and score in 1-9 scale, then a judgement matrix $G$ was obtained:

$$
G=\left[\begin{array}{cccc}
g_{11} & g_{12} & \cdots & g_{1 n} \\
g_{21} & g_{22} & \cdots & g_{2 n} \\
\vdots & \vdots & \cdots & \vdots \\
g_{n 1} & g_{n 2} & \cdots & g_{n n}
\end{array}\right]=\left[g_{i j}\right]_{n x n}, 1 \leq i, j \leq n
$$

where, $g_{i j}$ represents the judgement value of the $i$-th evaluation index relative to the $j$ th evaluation index, and there's $g_{i j}=1 / g_{j i}$.

The judgement matrix $G$ was calculated and analyzed to obtain the corresponding $n$-th $\operatorname{root} W_{i}(G)$ :

$$
W_{i}(G)=\sqrt[n]{\prod_{j=1}^{n} g_{i j}}
$$

Then, the weight of the $i$-th evaluation index $w_{i}(G)$ is:

$$
w_{i}(G)=W_{i}(G) / \sum_{j=1}^{n} W_{i}(G)
$$

Thus, the largest characteristic root $\lambda_{\max }(G)$ of the judgment matrix $G$ can be obtained:

$$
\lambda_{\max }(G)=\sum_{i=1}^{n}(G * \mathbf{W}(G))_{i} /\left(n * w_{i}\right)
$$

Perform consistency check on judgment matrix $G$ :

$$
C R=\frac{\lambda_{\max }(G)-n}{(n-1) * R I}
$$

where, $C R$ represents the consistency ratio, $R I$ represents the random index.

If there is $C R<0.1$, then it indicates that judgment matrix $G$ meets the requirement, and the corresponding evaluation index weight $w_{i}$ is reasonable; otherwise, the evaluation index weights need to be re-allocated until judgment matrix $G$ meets the requirement.

In order to reduce the influence of subjective factors, the evaluation index weights can also be obtained from the objective index values, and the entropy method was employed in this paper for processing. Under the premise that the normalized value $V_{j}^{*}\left(P_{i}\right)$ of the $j$-th evaluation index of the $i$-th evaluation object $P_{i}$ was obtained, the entropy value of the $j$-th evaluation index is:

$$
E_{j}=-\sum_{i=1}^{M}\left(\left(V_{j}^{*}\left(P_{i}\right) / \sum_{i=1}^{M} V_{j}^{*}\left(P_{i}\right)\right) * \ln \left(V_{j}^{*}\left(P_{i}\right) / \sum_{i=1}^{M} V_{j}^{*}\left(P_{i}\right)\right)\right) / \ln M
$$


Then, the actual weight value $w_{j}^{*}(E)$ of the $j$-th evaluation index is:

$$
w_{j}^{*}(E)=1-E_{j}, 1 \leq j \leq n
$$

Then, the relative weight $w_{j}(E)$ of the $j$-th evaluation index is:

$$
w_{j}(E)=w_{j}^{*}(E) / \sum_{j=1}^{n} w_{j}^{*}(E)=\left(1-E_{j}\right) / \sum_{j=1}^{n}\left(1-E_{j}\right)
$$

Under the condition that the influence of subjective and objective factors have been comprehensively considered, then the weight $w_{j}$ of the $j$-th evaluation index can be expressed as:

$$
w_{j}=\alpha * w_{j}(G)+\beta * w_{j}(E)
$$

where, $\alpha$ represents the weight coefficient of the evaluation index under the influence of subjective factors, and $\beta$ represents the weight coefficient of the evaluation index under the influence of objective factors, and they satisfy $\alpha+\beta=1$.

\subsection{Multi-attribute fuzzy evaluation model}

According to the gray system theory, under the condition that the normalized value $V_{j}^{*}\left(P_{i}\right)=\left[v_{j}^{a *}\left(P_{i}\right), v_{j}^{b *}\left(P_{i}\right)\right]$ of the $j$-th evaluation index of the $i$-th evaluation object $P_{i}$ was obtained, the gray comparison sequence $X\left(P_{i}\right)$ of evaluation objects $P_{i}$ in the implementation effect evaluation of digital media courses can be constructed as:

$$
X\left(P_{i}\right)=\left\{V_{1}^{*}\left(P_{i}\right), V_{2}^{*}\left(P_{i}\right), \cdots, V_{j}^{*}\left(P_{i}\right), \cdots, V_{n-1}^{*}\left(P_{i}\right), V_{j}^{*}\left(P_{i}\right)\right\}
$$

Similarly, the positive gray reference sequence $X^{\Delta}(P)$ of the evaluation of the implementation effect of digital media courses can be constructed:

$$
X^{\Delta}(P)=\left\{U_{1}^{*}(P), U_{2}^{*}(P), \cdots, U_{j}^{*}(P), \cdots, U_{n-1}^{*}(P), U_{j}^{*}(P)\right\}
$$

where, $U_{j}^{*}(P)=\max _{1 \leq i \leq M} V_{j}\left(P_{i}\right)$.

And the negative gray reference sequence $X^{\nabla}(P)$ of the evaluation of the implementation effect of digital media courses is:

$$
X^{\nabla}(P)=\left\{S_{1}^{*}(P), S_{2}^{*}(P), \cdots, S_{j}^{*}(P), \cdots, S_{n-1}^{*}(P), S_{j}^{*}(P)\right\}
$$

where, $U_{j}^{*}(P)=\max _{1 \leq i \leq M} V_{j}\left(P_{i}\right)$.

Then, the gray relation coefficient $\rho_{j}^{\Delta}\left(P_{i}\right)$ between the $i$-th evaluation object $P_{i}$ and the positive gray reference sequence $X^{\Delta}(P)$ with respect to the $j$-th evaluation index is: 


$$
\rho_{j}^{\Delta}\left(P_{i}\right)=\frac{\min _{i} \min _{j}\left(d\left(U_{j}^{*}(P) \rightarrow V_{j}^{*}\left(P_{i}\right)\right)\right)+\lambda * \max _{i} \max _{j}\left(d\left(U_{j}^{*}(P) \rightarrow V_{j}^{*}\left(P_{i}\right)\right)\right)}{d\left(U_{j}^{*}(P) \rightarrow V_{j}^{*}\left(P_{i}\right)\right)+\lambda * \max _{i} \max _{j}\left(d\left(U_{j}^{*}(P) \rightarrow V_{j}^{*}\left(P_{i}\right)\right)\right)}
$$

where, $\lambda$ represents the distinguishing coefficient, its value generally takes 0.5 .

The corresponding positive weighted gray relation degree $\varphi^{\Delta}\left(P_{i}\right)$ is:

$$
\varphi^{\Delta}\left(P_{i}\right)=\sum_{j=1}^{N}\left(w_{j} * \rho_{j}^{\Delta}\left(P_{i}\right)\right)
$$

Then, the gray relation coefficient $\rho_{j}^{\nabla}\left(P_{i}\right)$ between the $i$-th evaluation object $P_{i}$ and the negative gray reference sequence $X^{\nabla}(P)$ with respect to the $j$-th evaluation index is:

$$
\rho_{j}^{\nabla}\left(P_{i}\right)=\frac{\min _{i} \min _{j}\left(d\left(S_{j}^{*}(P) \rightarrow V_{j}^{*}\left(P_{i}\right)\right)\right)+\lambda * \max _{i} \max _{j}\left(d\left(S_{j}^{*}(P) \rightarrow V_{j}^{*}\left(P_{i}\right)\right)\right)}{d\left(S_{j}^{*}(P) \rightarrow V_{j}^{*}\left(P_{i}\right)\right)+\lambda * \max _{i} \max _{j}\left(d\left(S_{j}^{*}(P) \rightarrow V_{j}^{*}\left(P_{i}\right)\right)\right)}
$$

The corresponding negative weighted gray relation degree $\varphi^{\nabla}\left(P_{i}\right)$ is:

$$
\varphi^{\nabla}\left(P_{i}\right)=\sum_{j=1}^{N}\left(w_{j} * \rho_{j}^{\nabla}\left(P_{i}\right)\right)
$$

Therefore, it could be obtained that the comprehensive weighted gray relation degree $\varphi\left(P_{i}\right)$ of the $i$-th evaluation object $P_{i}$ is:

$$
\varphi\left(P_{i}\right)=1 /\left(1+\left(\varphi^{\nabla}\left(P_{i}\right) / \varphi^{\Delta}\left(P_{i}\right)\right)^{2}\right)
$$

According to the formula, greater $\varphi\left(P_{i}\right)$ value indicates better implementation effect of the digital media courses of the $i$-th evaluation object $P_{i}$; on the contrary, smaller $\varphi\left(P_{i}\right)$ value indicates worse implementation effect of the digital media courses of the $i$-th evaluation object $P_{i}$; if $\varphi\left(P_{i}\right)$ cannot meet the threshold requirement, it indicates that the curriculum setting of digital media major of the $i$-th evaluation object $P_{i}$ needs to be improved in a targeted manner.

\section{Conclusion}

This paper discussed the curriculum setting of digital media major in the digital age. After analyzing a few problems existing in the curriculum setting of digital media major, it pointed out essential elements in the curriculum setting of digital media major; then on this basis, to effectively improve the quality of the curriculum setting of digital media major, this paper proposed a few strategies and the corresponding implementation paths, which provided a useful instruction to point out the direction for the smooth implementation of digital media courses. At the same time, in order to effectively evaluate the implementation effect of the digital media courses, this paper 
also established an evaluation system and a multi-attribute fuzzy evaluation model, which provided good support for effectively judge the rationality and effectiveness of the digital media courses and improve the curriculum setting works of the digital media major in schools.

\section{Acknowledgment}

The writing of this paper was supported by the Humanities and Social Sciences Project of the Education Department of Jiangsu Province, "Research on the Digital Restoration and Display of Cultural Relics Based on Virtual Reality". Project Number: KZ2019039 Approval Number: 2019SJA0507.

\section{References}

[1] Bernátová, R., Bernát, M., Poráčová, J., Zahatňanská, M., Blaščáková, M.M., Konečná, M., Klučarová, A. (2020). System of logical structures in natural science-oriented curriculum and its effect on teaching. International Journal of Emerging Technologies in Learning, 15(22), 59-77. https://doi.org/10.3991/ijet.v15i22.17155

[2] Baig, A.R., Alotaibi, A. (2020). Effect of curriculum-based video games on students' performance: an experimental study. International Journal of Emerging Technologies in Learning, 15(22), 244-257. https://doi.org/10.3991/ijet.v15i22.15541

[3] Kustandi, C., Fadhillah, D.N., Situmorang, R., Prawiladilaga, D.S., Hartati, S. (2020). VR Use in Online Learning for Higher Education in Indonesia, International Journal of Interactive Mobile Technologies, 14(1), 31-47. https://doi.org/10.3991/ijim.v14i01.11337

[4] Hasanudin, C., Fitrianingsih, A., Saddhono, K. (2019). The use of wondershare filmora version 7.8.9 media apps in flipped classroom teaching. Review of Computer Engineering Studies, 6(3), 51-55. https://doi.org/10.18280/rces.060301

[5] Majid, N.W.A., Fuada, S. (2020). E-Learning for Society: A Great Potential to Implement Education for All (EFA) Movement in Indonesia, International Journal of Interactive Mobile Technologies, 14(2), 250-258. https://doi.org/10.3991/ijim.v14i02.11363

[6] May, D. (2020). Cross Reality Spaces in Engineering Education - Online Laboratories for Supporting International Student Collaboration in Merging Realities, International Journal of Online and Biomedical Engineering, 16(3), 4-26. https://doi.org/10.3991/ijoe .v16i03.12849

[7] Liao, J. (2021). On the Curriculum Design of Digital Media Technology Major. Digital Communication World, 2021(1): 228-229. https://doi.org/10.3969/J.ISSN.1672-7274 .2021 .01 .104

[8] Qin, X.J, Mi, A.Q., Qin, X.P. (2020). Research on curriculum setting of interactive direction of digital media art. Design, 33(17): 125-127.

[9] Duan, H.L., Wang, L., Wang, J. (2017). Construction and Discussion on the curriculum system of digital media application technology specialty in Higher Vocational Colleges. Science and Technology Innovation Herald, 14(29): 228-230. http://dx.doi.org/10.16660/ j.cnki.1674-098X.2017.29.228

[10] Liu, M., Mu, Z.H. (2017). Research on the course system construction of digital media technology specialty for the needs of enterprises. Education Circle, 2017(30): 105-106. http://dx.doi.org/10.3969/j.issn.1674-9510.2017.30.050 
[11] Shu, Z., Chen, L.Z., Zhao, H.J., Zhang, R.R. (2021). Research and Practice of Online Teaching of Digital Media Design Course for Printing Engineering Specialty. Modern Computer, 2021(1): 78-85. https://doi.org/10.3969/j.issn.1007-1423.2021.01.014

[12] Ghorbanian, A., Maghsoudi, Y., Mohammadzadeh, A. (2020). Clustering-based band selection using structural similarity index and entropy for hyperspectral image classification. Traitement du Signal, 37(5), 785-791. https://doi.org/10.18280/ts.370510

[13] Murugan, S., Kulanthaivel, G., Ulagamuthalvi, V. (2019). Selection of test case features using fuzzy entropy measure and random forest. Ingénierie des Systèmes d'Information, 24(3), 261-268. https://doi.org/10.18280/isi.240306

[14] Hasan, M.S.U., Rai, A.K. (2020). Groundwater quality assessment in the Lower Ganga Basin using entropy information theory and GIS. Journal of Cleaner Production, 274: 123077. https://doi.org/10.1016/j.jclepro.2020.123077

[15] Dobovišek, A., Markovič, R., Brumen, M., Fajmut, A. (2018). The maximum entropy production and maximum Shannon information entropy in enzyme kinetics. Physica A: Statistical Mechanics and its Applications, 496: 220-232. https://doi.org/10.1016/ j.physa.2017.12.111

[16] Li, Y.P., Jin, D.M. (2020). A model for the influential factors of the autonomous learning ability of Japanese majors. International Journal of Emerging Technologies in Learning, 15(12), 153-167. https://doi.org/10.3991/ijet.v15i12.14531

[17] Kursunoglu, S., Ichlas, Z.T., Kaya, M. (2017). Leaching method selection for Caldag lateritic nickel ore by the analytic hierarchy process (AHP). Hydrometallurgy, 171: 179184. http://dx.doi.org/10.1016/j.hydromet.2017.05.013

[18] Fernando, E., Siagian, P. (2021). Proposal to use the Analytic Hierarchy Process Method Evaluate Bank Credit Submissions. Procedia Computer Science, 179: 232-241. https://doi.org/10.1016/j.procs.2021.01.002

[19] Becker, U., Manz, H. (2016). Grey systems theory time series prediction applied to road traffic safety in Germany. IFAC-PapersOnLine, 49(3): 231-236. https://doi.org/10.1016/ j.ifacol.2016.07.039

\section{Authors}

Zhiqi Zhou is a Chinese animation artist and digital media art educator. At the same time, he is the director of the visual media department of the Art College of Sanjiang University. He is also a member of Jiangsu arts and Crafts Industry Association and Animation Association. Email: zhou_zhiqi@sju.edu.cn

Bo Dong is an associate professor at Chuzhou Vocational and Technical College. At the same time, he is also an expert of Anhui Comprehensive Bid Evaluation and Evaluation Expert Database and an expert of Chuzhou Construction Engineering and Municipal Infrastructure Engineering Quality and Safety Expert Database. Email: dongbo@chzc.edu.cn

Article submitted 2021-06-13. Resubmitted 2021-07-22. Final acceptance 2021-07-23. Final version published as submitted by the authors. 